\title{
OD RZECZY DO PODMIOTU. PRAKTYCZNE IMPLIKACJE ETYKI OCHRONY ZWIERZĄT
}

\section{Wprowadzenie}

Etyka środowiskowa ukonstytuowała się na przełomie lat siedemdziesiątych i osiemdziesiątych XX w. ${ }^{1} \mathrm{U}$ jej podstawy leży teza, że troska o przyszłość ludzkości staje się nadrzędnym obowiązkiem człowieka, żyjącego we współczesnej cywilizacji technicznej. Metafizyczna odpowiedzialność wykracza poza jednostkowy los homo sapiens. Zaczyna dotykać reszty świata ożywionego. ${ }^{2}$ Spojrzenie takie wiąże się z ideą zrównoważonego rozwoju, a także zbiorowej odpowiedzialności wobec innych organizmów żywych i przyszłych pokolen. ${ }^{3}$ Coraz częściej zauważa się konieczność redefinicji kategorii przyrody zgodnie z uwzględnieniem interesów czynników pozaludzkich. ${ }^{4}$

Etyka ochrony zwierząt (animal ethics) ma swoje źródła w refleksji etyki środowiskowej. Zwierzęta wkroczyły w „uniwersum moralne”, zarezerwowane dotychczas wyłącznie dla ludzi, a ich los stał się fundamentalnym problemem etycznym. ${ }^{5}$ Nastąpiła zmiana optyki: od dominującego przez wieki w kulturze Zachodu antropocentryzmu w kierunku biocentryzmu. ${ }^{6}$

Zmiany w kulturowo utrwalonym paradygmacie, polegające na uwzględnianiu autonomicznej wartości pozaludzkich istot żywych „,...) musiały znaleźć odzwierciedlenie w nowej propozycji rozumienia filozofii prawa chociażby $\mathrm{z}$ tego powodu,

\footnotetext{
1 Z. Hull, Ekofilozofia i etyka środowiskowa - czy etyka środowiskowa jest częścią ekofilozofii, [w:] K. Kalka, A. Papuziński (red.), Etyka wobec współczesnych dylematów, Bydgoszcz 2006, s. 309-310.

2 H. Jonas, Zasada odpowiedzialności, Kraków 1996, s. 249.

3 E. Bończyk, Technonauka w społeczeństwie ryzyka. Filozofia wobec niepożądanych następstw praktycznego sukcesu nauki, Toruń 2012, s. 169.

$4 \quad$ Ibidem, s. 170

5 D. Liszewski, Czy etyka ochrony zwierząt należy do etyki środowiskowej, [w:] K. Kalka, A. Papuziński (red.), Etyka..., op. cit., s. 319.

6 R.A. Tokarczyk, Biojurysprudencja. Podstawy prawa dla XXI w., Lublin 2008, s. 30-31.
} 
że dotychczasowe prawo stanowione nadal honoruje umocowany w filozoficzno-religijnej tradycji ontyczny status zwierząt jako istot hierarchicznie niższych"? ${ }^{7}$

Prawa zwierząt przeszły dotąd przez dwa etapy rozwoju: konceptualizacji i normatywizacji. Kolejna faza polegać ma na ich pozytywizacji, czyli ogłoszeniu oraz skatalogowaniu w źródłach prawa publicznego. ${ }^{8}$

Prowadzona na świecie debata etyczna dotycząca praw zwierząt znajduje stosunkowo niewielki oddźwięk w Polsce. Źródeł tego stanu rzeczy można dopatrywać się w wielowiekowej tradycji religijnej, zgodnie z którą człowiek ma przyrodzone prawo do panowania nad zwierzętami oraz ich eksploatacji. Dlatego też zasadne będzie przyjrzenie się historycznym aspektom stosunku człowieka do zwierząt.

\section{Od reifikacji ku upodmiotowieniu zwierząt}

Przez długi czas zwierzęta stanowiły przede wszystkim przedmiot uprawnień przysługujących ludziom, w tym głównie prawa własności. ${ }^{9}$

Tendencje reifikacji zauważalne były już w czasach starożytnych. Za sprawą Arystotelesa, uznawano powszechnie, że zwierzę jest „niewolnikiem z natury”, zaś głównym jego celem staje się służenie obywatelom. Równolegle pojawiały się wprawdzie poglądy wskazujące na anatomiczne, fizjologiczne oraz intelektualne podobieństwa pomiędzy człowiekiem a zwierzęciem. Nie miały one jednak większego wpływu na zmianę ludzkiej mentalności i relacji: człowiek-zwierzę.

Pod wpływem chrześcijaństwa zwierzętom zaczęto odmawiać jakichkolwiek uprawnień czy nawet samodzielnego znaczenia moralnego. Wiązało się to z uznaniem, że tylko człowiek został stworzony na obraz i podobieństwo boże, zaś wszystko co żyje ma mu służyć. Antropocentryczne spojrzenie uwidoczniło się w rozważaniach św. Augustyna i Tomasza z Akwinu. Wraz z rozwojem chrześcijańskiego antropocentryzmu można było wyraźnie zauważyć, że im większą wartość przypisywano życiu ludzkiemu, tym niższy stawał się status zwierząt.

Idee humanizmu epoki odrodzenia nie wiązały się z humanitaryzmem wobec zwierząt. Przeciwnie, eksponowanie różnic pomiędzy człowiekiem a zwierzęciem przyczyniło się do rozwoju szowinizmu gatunkowego. Poglądy prozwierzęce należały do rzadkości, tym niemniej były czasem prezentowane. Za rzeczników zwierząt tamtego okresu uznać można m.in. L. da Vinci, G. Bruno i M. de Montaigne.

Instrumentalne traktowanie zwierząt znalazło swoje odzwierciedlenie w poglądach filozofów okresu oświecenia. Szczególny wpływ na praktykę traktowania zwierząt wywarła myśl Kartezjusza. Zrównał on zwierzęta z maszynami, pozbawionymi duszy i świadomości. Bardzo radykalne okazały się twierdzenia I. Kanta, który

\footnotetext{
D. Probucka, Filozoficzne podstawy idei praw zwierzạt, Kraków 2013, s. 46.

J. Białocerkiewicz, Prawny status zwierząt. Prawa zwierząt czy prawna ochrona zwierząt, Toruń 2005, s. 185.

I. Lazarii-Pawłowska, Zwierzę nie jest rzeczą, [w:] Etyka. Pisma wybrane, Wrocław-Warszawa-Kraków 1992, s. 32 .
} 
przyjmował, iż zwierzęta nie mogą być podmiotami żadnych uprawnień, a ludzie nie mają względem nich moralnych obowiązków. ${ }^{10}$

Dobrą podstawą do wyrażania stanowiska przez obrońców praw zwierząt okazał się dopiero utylitaryzm. Czołowy utylitarysta - J. Bentham, podkreślał, że zwierzęta, tak jak ludzie, zdolne są do odczuwania bólu. Zgodnie z zasadami utylitarystycznego rachunku uznał, że przeprowadzanie eksperymentów na zwierzętach powinno być dopuszczone jedynie w niezbędnym zakresie; tylko wtedy, jeśli doświadczenia takie służyć mają dobru ludzkości. Bezcelowe męczarnie traktował jako jednoznaczne okrucieństwo. ${ }^{11}$

Rozumienie relacji między ludźmi i zwierzętami całkowicie zmieniła dopiero teoria ewolucji. Za sprawą K. Darwina i jego przełomowej pracy pt. O pochodzeniu gatunków okazało się, jak niewielkie różnice zachodzą pomiędzy zwierzętami a ludźmi.

Do radykalnych zmian w myśleniu o zwierzętach przyczyniły się prace autorów przełomu XIX i XX w., takich jak: J. Boehme, L. Compertz, H. Salt, E.W. Nicholson. Godna odnotowania jest publikacja polskiego prawnika, socjologa i publicysty - B. Łozińskiego pt. Prawo zwierzat. Studium Socjologiczne, wydana w 1895 r. we Lwowie. ${ }^{12}$

Dzięki systematycznie gromadzonej wiedzy, wraz z nastaniem w nauce kognitywnego podejścia do zachowania zwierząt, zaczął ugruntowywać się pogląd o obecności wśród rozmaitych gatunków zdolności do działania intencjonalnego, planowania, różnych sposobów komunikacji, a nawet samoświadomości. ${ }^{13}$

\section{Współczesne nurty dyskusji etycznej na temat praw zwierząt}

Wzrost zainteresowania filozoficzną koncepcją praw zwierząt nastąpił w latach sześćdziesiątych XX w., za sprawą grupy intelektualistów z Oxford University, którzy sprzeciwili się okrutnemu traktowaniu zwierząt w laboratoriach i przemysłowych hodowlach. Prace takich autorów, jak np.: R. Harrisom, B. Brophy, R.D. Ryder, J. Harris, S. Godlovitch, R. Godlovitch, miały istotny wpływ na postrzeganie relacji: człowiek - zwierzę.

W rozważaniach z zakresu etyki ochrony zwierząt zaczął się formować nurt poszanowania interesów zwierząt (animal welfare). Rozwijał się on pod wpływem rewolucyjnych poglądów P. Singera, zaprezentowanych w książce pt.: Animal Li-

\footnotetext{
10 Patrz szerzej: T. Pietrzykowski, Spór o prawa zwierząt. Etyczne problemy prawa, Katowice 2007, s. 20; tenże: Wyzwania moralne. Etyczne problemy prawa, Katowice 2010, s. 168; D. Probucka, Filozoficzne podstawy..., op. cit., s. 273-304.

11 J. Bentham, Wprowadzenie do zasad moralności i prawodawstwa, Kraków 1958, s. 418-420.

12 D. Probucka, Filozoficzne podstawy..., op. cit., s. 22-24.

13 F. de Waal, Małpy i filozofowie. Skąd pochodzi moralność?, Kraków 2013, s. 102.
} 
beration (Wyzwolenie zwierzat), wydanej w 1975 r. Praca ta stworzyła mocne fundamenty dla wszelkich współczesnych ruchów zajmujących się ochroną zwierząt. ${ }^{14}$

Zdaniem P. Singera, obowiązkiem każdego człowieka powinno być stosowanie „zasady równego poszanowania interesów” (the principle of equal consideration of interests) wszystkich istot zdolnych do doświadczania cierpienia. ${ }^{15} \mathrm{Z}$ etycznego punktu widzenia równym interesom rozmaitych istot, niezależnie jaki gatunek reprezentują, przynależny jest równy szacunek. W sytuacji, gdy mamy do czynienia $\mathrm{z}$ istotami jednakowo zdolnymi do odczuwania cierpienia, zadawanie im bólu zasługuje na jednakową negatywną ocenę moralną. ${ }^{16}$

Przyjęcie zasady równego poszanowania interesów prowadzić musiało do radykalnych zmian w relacjach: ludzie - zwierzęta. Za naganne zaczęto uznawać zabijanie zwierząt $w$ celu realizacji egoistycznych zachcianek człowieka i wykorzystywanie ich dla rozrywki. Singer podkreśla, że przejawem moralnego zła jest w szczególności sposób uśmiercania i traktowania zwierząt, powodujący cierpienie. Filozof proponuje takie środki działania, które mogłyby zmniejszyć wymiar cierpień zwierząt. Chodzi mu m.in. o zaprzestanie wspierania ferm przemysłowych oraz innych nowoczesnych form intensywnej hodowli zwierząt na mięso. ${ }^{17}$

$\mathrm{O}$ wiele bardziej radykalny w swoich poglądach okazuje się T. Regan, główny rzecznik drugiego nurtu w etyce ochrony zwierząt - ochrony praw zwierząt (animal rights). W swojej pracy pt.: The Case For Animal Rights formułuje on tezę o posiadaniu przez zwierzęta własnych, podmiotowych uprawnień (basic moral rights). Uprawnienia te wymagają takiego samego poszanowania, jak prawa człowieka. Istoty pozaludzkie, jako zdolne do odczuwania bólu (sentient beings), mają w szczególności moralne prawo do poszanowania życia i cielesnej integralności, prawo do unikania cierpienia, prawo do poszanowania wolności, a nawet prawo do godności. Filozof jest przekonany, że te moralne uprawnienia nie przynależą $\mathrm{w}$ równym stopniu wszystkim istotom zdolnym do odczuwania bólu. Posiadają je tylko te zwierzęta, które można zaliczyć do kategorii „podmiotów życia” (subject-of-a-life), czyli wszystkie ssaki oraz ptaki.

Zdaniem T. Regana w cywilizowanych społeczeństwach ludzkich nie wystarczy troska o poprawę warunków bytowych zwierząt w laboratoriach, rzeźniach, czy przemysłowych hodowlach. Nie wystarczy minimalizacja cierpień. Obowiązkiem moralnym ludzi jest eliminacja wszystkich instytucjonalnych form wyzysku zwierząt, wszelkich sposobów ich eksploatacji. Chodzi zatem nie o to, aby klatki były wygodniejsze, lecz o to, by były one puste. ${ }^{18}$ Konsekwencją takiego spojrzenia są ra-

\footnotetext{
14 J. Synowiec, Jakie Peter Singer rzuca nam wyzwania, [w:] J. Ziobrowski (red.), Etyka u schyłku drugiego tysiąclecia, Warszawa 2013, s. 219.

15 P. Singer, O życiu i śmierci. Upadek etyki tradycyjnej, Warszawa 1997, s. 41 i nast.

16 P. Singer, Etyka praktyczna, Warszawa 2007, s. 83-109.

17 P. Singer (red.), Wyzwolenie zwierząt, Warszawa 2011, s. 319; P. Singer (red.), W obronie zwierząt, Warszawa 2011, s. 318-320.

18 T. Regan, Filozofia praw zwierząt, [w:] W. Owczarz (red.), Antologia praw zwierząt, Bielsko-Biała 1995, s. 82.
} 
dykalne postulaty zakazów: funkcjonowania ferm hodowlanych, polowań, eksperymentów na zwierzętach, wykorzystywania zwierząt dla rozrywki, spożywania mięsa itp. ${ }^{19}$ Regan podejmuje zatem próbę radykalnej zmiany kulturowo utrwalonego statusu zwierząt jako ludzkiej własności. W przeciwieństwie do Singera wyklucza jakiekolwiek możliwości ich wykorzystywania. ${ }^{20}$

\section{Prawne implikacje idei wyzwolenia zwierząt: przepisy ochronne i tendencje pozytywizacji praw zwierząt}

Na przełomie kilkudziesięciu zaledwie lat, pod wpływem doktrynalnych ustaleń na gruncie etyki ochrony zwierząt, powstało wiele regulacji prawnych o charakterze ochronnym, które miały wyeliminować (lub przynajmniej ograniczyć) najbardziej drastyczne przejawy zorganizowanego okrucieństwa wobec zwierząt.

W 1977 r. organizacje i ruchy ochrony praw zwierząt tworzące Międzynarodową Federację Praw Zwierząt przygotowały i przyjęły Światową Deklarację Praw Zwierząt, wzorowaną na Powszechnej Deklaracji Praw Człowieka ONZ. Deklaracja została proklamowana przez UNESCO w Paryżu w dniu 13 października 1978 r. Stanowi ona swoisty manifest podstawowych idei i celów, jakimi kieruje się współczesny ruch wyzwolenia zwierząt.

Ogromną rolę w „humanizowaniu prawa” odnośnie do sposobu traktowania zwierząt odegrała Rada Europy, tworząc szereg konwencji międzynarodowych. ${ }^{21}$ Wraz z Traktatem Amsterdamskim w prawie wspólnotowym doszło do przyjęcia w 1997 r. Protokołu dodatkowego o ochronie i dobru zwierząt, z którego wynika, że Unia Europejska i państwa członkowskie mają respektować wymagania należytego traktowania zwierząt. Parlament Europejski w przyjętym w 2006 r. Wspólnotowym planie działań na rzecz ochrony i dobrostanu zwierząt wyraził tezę, że ochrona zwierząt jest w XXI w. wyrazem człowieczeństwa oraz wyzwaniem dla europejskiej cywilizacji i kultury. Teza ta została wielokrotnie powtórzona w innych dokumentach. ${ }^{22}$

Polska ustawa o ochronie zwierząt definiuje zwierzę jako istotę czującą, zdolną do odczuwania cierpienia. ${ }^{23}$ Twórca prawa wyraźnie określa, że zwierzę nie jest rzeczą oraz że człowiek winien mu poszanowanie, ochronę i opiekę. Z ustawy wynika obowiązek humanitarnego traktowania zwierząt. Znowelizowaną w 2011 r. ustawę należy niewątpliwie uznać za początek przełomu dotyczącego sytuacji zwierząt $\mathrm{w}$ naszym kraju. $\mathrm{Z}$ drugiej jednak strony regulacja ta $\mathrm{w}$ ostatecznym rozrachunku służy przede wszystkim dobru człowieka; trosce o nienaruszalność mienia prywat-

\footnotetext{
19 T. Pietrzykowski, Spór o prawa zwierząt..., op. cit., s. 90-107.

20 D. Probucka, Filozoficzne podstawy..., op. cit., s. 27.

21 H. Machińska, System prawa konwencyjnego Rady Europy w dziedzinie ochrony zwierząt, [w:] T. Gardocka, A. Gruszczyńska (red.), Status zwierzęcia. Zagadnienia filozoficzne i prawne, Toruń 2012, s. 273-287.

22 J. Wojciechowski, Ochrona zwierząt w UE - w dobrym kierunku zbyt małymi krokami, [w:] T. Gardocka, A. Gruszczyńska (red.), Status zwierzęcia..., op. cit., s. 291-295. 
nego, państwowego, ewentualnie zapobieganiu społecznemu oburzeniu. ${ }^{24}$ Pomimo deklarowanej dereifikacji zwierzę chociaż nie jest rzeczą, jednocześnie w praktyce jest nią nadal. ${ }^{25}$ Zwierzęta hodowlane wciąż mogą być przedmiotem obrotu cywilnoprawnego. Człowiekowi przysługuje względem nich prawo własności w sensie ekonomicznym. Zgodnie z art. 140 Kodeksu cywilnego przedmiotem własności może być rzecz, zaś z art. 1 ustawy o ochronie zwierząt (ust. 2) wynika, że w sprawach nieuregulowanych ustawą wobec zwierząt należy stosować przepisy dotyczące rzeczy. Można stwierdzić, że w istocie ustawa ogranicza jedynie prawa własnościowe człowieka, zakazując okrutnego traktowania istot pozaludzkich, czyli zadawania im dotkliwego bólu, głodzenia, okaleczania lub niewolniczego wykorzystywania do pracy. Niezależnie od tego przychówek zwierząt hodowlanych traktowany jest jako tzw. „,pożytki naturalne” rzeczy; zaś w kontekście przepisów określających zwierzę jako przedmiot umowy kupna-sprzedaży wspomina się o odpowiedzialności za wady fizyczne rzeczy. Biorąc pod uwagę powyższe realia D. Probucka sceptycznie zauważa: „(...) twierdzenie, że zwierzę nie jest rzeczą, powinniśmy zinterpretować jako przykład tzw. fikcji prawnej."26

Rację ma T. Kozłowski, który pisze, że „reakcje na prawa zwierząt są swoistym papierkiem lakmusowym stanu społecznej świadomości". ${ }^{27}$ Świadomość społeczeństwa polskiego przesiąknięta jest antropocentryzmem. Wydaje się, że warunkiem poprzedzającym zmiany prawne w kwestii ochrony zwierząt powinny być głębokie przeobrażenia w społecznej sferze mentalnej. Wiążą się one jednak z długotrwałym procesem edukacyjnym: „Wpisywanie zwierząt w prawo uczy nas, iż mimo dwóch tysięcy lat pojmowania prawa i mimo powszechności uznania takich pojęć jak «rządy prawa» za pomniki kultury Zachodu nadal jesteśmy na początku tego, co prawne. Pomysł na prawo ugrzązł w tym, co religijne, co moralne, władcze, interesowne. Prawo nadal nie zdobyło się na uznanie swej pełnej niezależności, właśnie tak dobrze widocznej w odnoszeniu się człowieka do zwierząt" ${ }^{28}$ Powyższa uwaga T. Kozłowskiego ma wprawdzie charakter generalnej oceny, tym bardziej jednak prawdziwa okazuje się w odniesieniu do polskiej rzeczywistości, gdzie na realne efekty transformacji stosunku człowieka do zwierząt trzeba będzie jeszcze zapewne długo poczekać.

Podczas gdy w Polsce zwierzęta w dalszym ciągu są traktowane rzeczowo, zaś dereifikacja ma charakter fikcyjny, w innych demokratycznych państwach intensyfikuje się proces upodmiotowienia zwierząt. Postuluje się wręcz niekiedy przyznanie im praw równych ludziom (przynajmniej jeśli chodzi o niektóre gatunki). Ma

24 J. Białocerkiewicz, Prawny..., op. cit., s. 235.

25 D. Probucka, Filozoficzne podstawy..., op. cit., s. 306.

26 Ibidem.

27 T. Kozłowski, Wyzwolenie prawa - prawność i prawna ochrona zwierząt, [w:] T. Gardocka, A. Gruszczyńska (red.), Status zwierzęcia..., op. cit., s. 125. 
to swoje odzwierciedlenie w praktyce stosowania prawa oraz rzutuje na kierunki prawotwórstwa. ${ }^{29}$

Nie tak dawno organizacja broniąca praw zwierząt People for the Ethical Treatment of Animals (PETA) wniosła do sądu pozew, w którym domaga się zniesienia niewolnictwa w stosunku do morskich ssaków - delfinów i wielorybów. Organizacja ta powołała się na 13 poprawkę do Konstytucji USA z 1865 r., znoszącą niewolnictwo, twierdząc, że zwierzęta w ogrodach zoologicznych i delfinariach wiodą żywot niewolników. PETA domaga się objęcia ich prawem do życia, wolności i ogólnie przyjętego dobrobytu.

Warto zwrócić uwagę na niedawną inicjatywę znanych naukowców, którzy utworzyli Great Ape Project (Projekt Wielkich Małp) - międzynarodową organizację, domagającą się podstawowych praw dla wielkich małp człekokształtnych. Projektowi temu towarzyszyła książka Great Ape Project: Equality Beyond Humanity, która zawiera teksty uczonych w dziedzinie zachowania wielkich małp. Rozpoczyna się ona od Deklaracji Praw Wielkich Matp, którą zgodzili się poprzeć wszyscy autorzy i która z założenia miałaby pełnić rolę podobną do Powszechnej Deklaracji Praw Człowieka. W deklaracji domagają się oni poszerzenia o wielkie małpy tego, co nazywają ,wspólnotą równych”. Chodzi o „wspólnotę moralną”, w ramach której wzajemnymi relacjami rządzą określone podstawowe zasady oraz prawa moralne egzekwowalne prawnie. Wśród tych zasad i praw wymienione są: prawo do życia, ochrona wolności osobistej oraz zakaz tortur. ${ }^{30}$ Jak obrazowo podkreślił P. Singer, jednym z powodów przyznania wielkim małpom specjalnego statusu jest to, że „(...) wielkie małpy mogą nam pomóc przerzucić most nad przepaścią, którą tysiąclecia judeochrześcijańskiej indoktrynacji wykopały między nami a innymi zwierzętami. Uznanie, że wielkie małpy mają prawa podstawowe, pomogłoby nam dostrzec, że różnice między nami a innymi zwierzętami są natury ilościowej, co mogłoby doprowadzić do lepszego traktowania wszystkich zwierząt". ${ }^{31}$

\section{Etyczne aspekty uboju rytualnego i myślistwa}

Ubój rytualny to tylko „wierzchołek góry” problemów, które biorą się ze sposobu, w jaki ludzie traktują dziś zwierzęta. Można wysunąć wątpliwość, czy w erze hodowli przemysłowej humanitarne zabijanie zwierząt jest w ogóle możliwe. W hodowli takiej liczy się przede wszystkim ilość. Nie ma czasu na refleksje dotyczące etyki zabijania. ${ }^{32}$ Hodowcy stłaczają jak najwięcej zwierząt w jednym miejscu,

Przykładem upodmiotowienia zwierząt jest chociażby prawo do dziedziczenia przyznane zwierzętom na gruncie ustawodawstwa 19 stanów USA, albo paszport zwierzęcia funkcjonujący w UE, czy też międzynarodowe regulacje dotyczące zakazu znęcania się nad zwierzętami; patrz szerzej: D. Bunikowski, Podstawowe kontrowersje dotyczące ingerencji prawa w sferę moralności, Toruń 2010, s. 361.

F.de Waal, Małpy i filozofowie..., op. cit., s. 185-185.

Ibidem, s. 190.

J. McMahann, Etyka zabijania, Warszawa 2012, s. 256-257. 
w ciasnych boksach i klatkach. Proces zabijania jest tak urządzony, żeby odbywało się ono jak najszybciej i jak najbardziej dochodowo. Wypracowane standardy prawne mają wprawdzie humanizować metody i warunki uboju, ale czy „uczłowieczenie" zabijania jest w ogóle możliwe?

W kontekście przemysłowej hodowli ubój rytualny może się wydawać problemem pobocznym. Spór wokół niego obrazuje jednak stan kondycji moralnej ludzi XXI w. Zadziwiające jest, że w obecnych czasach nadal praktykuje się składanie ofiar ze zwierząt. Pojawia się pytanie: czy powinno być miejsce na barbarzyńskie rytuały, które nie przystają do współczesności, nawet jeśli odbywają się w imię najbardziej szczytnych religijnych idei? Czy prawo ma dawać przyzwolenie na taki proceder?

W Polsce dyskusja na temat uboju rytualnego zintensyfikowała się w $2013 \mathrm{r}$. Okazało się, że zgoda na tego typu metodę zabijania stanowiła swoisty wyjątek od przewidzianej przez znowelizowaną ustawę o ochronie zwierząt zasady humanitarnego uboju. Przypomnieć należy, że w 1997 r. ustawodawca wprowadził przepis zawierający odstępstwo od obowiązku ogłuszenia zwierzęcia przed rozpoczęciem wykrwawienia, który dotyczył przypadku poddawania zwierząt szczególnym sposobom uboju, przewidzianym przez porządki religijne. W 2002 roku został on skreślony ${ }^{33}$ Pomimo tej zmiany, w wydanym przez Ministra Rolnictwa i Rozwoju Wsi rozporządzeniu z 2004 r. określone zostały zasady uboju rytualnego. Z rozporządzenia wynika, że bydło poddawane ubojowi zgodnie z obyczajami religijnymi zarejestrowanych związków wyznaniowych ma być unieruchamiane przy użyciu mechanicznych urządzeń służących do krępowania i zabijane bez ogłuszania. ${ }^{34}$

Ubój zwierząt bez pozbawienia ich świadomości można ocenić jako drastyczny i obcy europejskiej kulturze sposób zabijania, jednoznacznie pozbawiony humanitaryzmu. Zezwolenie na tego typu praktyki miało być wyrazem zapewnienia mniejszościom religijnym wolności sumienia i wyznania. Od 2013 r. roku nabyło moc obowiązującą rozporządzenie unijne dopuszczające wprawdzie ubój rytualny, jednak pozwalające poszczególnym państwom utrzymać jego zakaz. Polska dokonała notyfikacji w Komisji Europejskiej, z której wynika, że ubój bez ogłuszania jest zakazany.

Obok uboju rytualnego wiele kontrowersji wywołuje również proceder polowania na zwierzęta. Praktyka taka znajduje wielu aktywnych zwolenników i cieszy się dużą społeczną akceptowalnością. Coraz częściej pojawiają się jednak opinie, że powinna zostać zdelegalizowana. Podstawy do stworzenia stosownych regulacji daje sama ustawa o ochronie zwierząt, z której wynika przecież, że żadne zwierzę nie może stawać się przedmiotem maltretowania i ataków okrucieństwa. Patrząc na problem myślistwa od strony etycznej, trudno się oprzeć wrażeniu, że zabijanie

Dz.U. 2002, nr 135, poz. 1141.

A. Gruszczyńska, O zabijaniu - zarys problematyki pozbawiania życia zwierząt przeznaczonych do celów gospodarczych, [w:] T. Gardocka, A. Gruszczyńska (red.), Status zwierzęcia..., op. cit., s. 326-327. 
zwierząt wyłącznie dla rozrywki jest aktem niegodnym człowieka cywilizowanego. Polowanie jawi się - wraz z wyalienowaniem człowieka z przyrody - jako absolutnie ,,asymetryczne” (zwierzę w nierównej walce z człowiekiem nie ma bowiem żadnych szans). Wydaje się też całkowicie zbędne, gdyż zabijanie zwierząt w trakcie polowań nie ma obecnie żadnego związku z rzeczywistymi żywieniowymi potrzebami ludzi. Zabija się wyłącznie dla przyjemności, a to należy uznać za kompletną degradację moralną; działanie w oczywisty sposób nieetyczne, na które nie powinno być miejsca we współczesnych społeczeństwach ludzkich.

\section{Podsumowanie}

Dereifikacja zwierząt generuje postulat ich personifikacji - przyznania im podmiotowości prawnej i praw podmiotowych. Taki kierunek rozwoju praw zwierząt prognozuje J. Białocerkiewicz. Jego zdaniem, postulowana podmiotowość powinna mieć tzw. „funkcjonalny status”, zgodnie z którym każde zwierzę (odpowiednio do taksonomicznego podziału przeprowadzonego w oparciu o kryterium wrażliwości na ból i stopień samoświadomości) posiadałoby pewne prawa, których żaden człowiek nie powinien lekceważyć. ${ }^{35}$ Ograniczanie się jedynie do prawnej ochrony zwierząt nie wydaje się wystarczające. Pozytywizacja praw zwierząt ma spowodować, że uprawnienia takie nie będą mogły być arbitralnie modyfikowane, uchylane czy też ograniczane; tak, jak się to dzieje w przypadku istnienia przepisów ochronnych (czasowo i treściowo zmiennych, zależnych od politycznych i administracyjnych czynników).

T. Kozłowski z goryczą ocenia, że współczesne prawo w odniesieniu do kwestii ochrony zwierząt zostało „(...) spętane przez inne normy społeczne, a czasami zupełnie przez nie przykryte. Zupełnie jak te zwierzęta, pętane na co dzień przez człowieka na niezliczone sposoby, a nawet zupełnie ukryte przed szacownym obliczem człowieka i pojawiające się jako mięso na jego stole. Przypomina to prawo, które coś każe, ale już nikt nie pamięta dlaczego i nawet się tym nie interesuje, uznając takie próby za z góry skazane na porażkę". ${ }^{36}$ Pozytywizację praw zwierząt bez wątpienia opóźniają mentalne uwarunkowania w społeczeństwie. Ponadto, w interakcjach pomiędzy ludźmi a zwierzętami, nadal zauważalne są silne znamiona ,moralnej schizofrenii", o której pisał G.L. Francione w książce Introduction to Animal Rights: Your Child or the Dog. ${ }^{37}$ Jednak pomimo sceptycznych ocen perspektyw pozytywizacji praw zwierząt, dotychczasowe dokonania ruchu wyzwolenia zwierząt oraz ist-

35 J. Białocerkiewicz, Prawny..., op. cit., s. 265.

36 T. Kozłowski, Wyzwolenie prawa..., op. cit., s. 126.

37 „Moralna schizofrenia” może być rozumiana do opisu niespójnej postawy ludzi wobec zwierząt (,jedne kochasz, drugie zjadasz?"); zob. więcej: D. Gryza, Teoria praw zwierząt Toma Regana, [w:] T. Gardocka, A. Gruszczyńska (red.), Status zwierzęcia..., op. cit., s. 59. 
niejące już regulacje prawne, które uwzględniają podmiotowość zwierząt, pozwalają $\mathrm{z}$ nadzieją patrzeć $\mathrm{w}$ przyszłość.

Sposobów przezwyciężenia problemów związanych z niehumanitarnym traktowaniem zwierząt należy upatrywać nie tylko w zmianach świadomości społeczeństwa oraz podążających za nimi zmianach prawa, ale także w możliwościach współczesnej nauki. Przemysł tekstylny - dzięki współczesnym technologiom - daje możliwości sztucznego pozyskiwania tzw. „skóry ekologicznej”, co wiąże się z eliminacją zwierząt jako dawców skóry i futra na wyroby odzieżowe. Naukowe dane wskazują na bezzasadność doświadczeń na zwierzętach, zwłaszcza w obliczu badań farmakologicznych alternatywnych dla laboratoryjnych testów na zwierzętach. Dzięki inżynierii genetycznej produkuje się tzw. „żywność funkcjonalną”, bazującą na uprawach roślinnych, wzbogaconą o żelazo i witaminy. Pojawiły się alternatywne sposoby „wyżywienia ludzkości” dzięki mięsu hodowanemu dla celów spożywczych z komórek macierzystych in vitro. ${ }^{38}$ Być może niebawem ziści się więc wizja W. Churchila, który już w 1932 r. prognozował, że z czasem człowiek uwolni się od absurdu hodowania całego kurczaka, po to tylko, by zjeść nóżkę.

We współczesnym świecie, zwłaszcza w obliczu możliwości nauki, prawa zwierząt na pewno nie powinny pozostawać retorycznym zwrotem, skrótem myślowym, politycznym sloganem, albo prawniczą metaforą. Pozytywizacja tych praw staje się wręcz koniecznością, świadczącą o „człowieczeństwie” cywilizowanych ludzi. Można podejrzewać, że dopóki człowiek będzie okrutny wobec zwierząt, to nie wyzbędzie się również okrucieństwa względem siebie oraz innych przedstawicieli swojego gatunku. Okrucieństwo wobec „słabszych” zawsze demoralizuje; tym bardziej, jeśli jest legitymizowane przez władzę. Współczesne demokratyczne państwa nie powinny się na to godzić.

\section{BIBLIOGRAFIA}

Bentham J., Wprowadzenie do zasad moralności i prawodawstwa, Kraków 1958.

Białocerkiewicz J., Prawny status zwierząt. Prawa zwierząt czy prawna ochrona zwierząt, Torun 2005.

Bończyk E., Technonauka w społeczeństwie ryzyka. Filozofia wobec niepożądanych następstw praktycznego sukcesu nauki, Torun 2012.

Bunikowski D., Podstawowe kontrowersje dotyczące ingerencji prawa w sferę moralności, Torun 2010.

Gardocka T., Gruszczyńska A. (red.), Status zwierzęcia. Zagadnienia filozoficzne i prawne, Torun 2012.

Jonas H., Zasada odpowiedzialności, Kraków 1996.

Kalka K., Papuziński A. (red.), Etyka wobec współczesnych dylematów, Bydgoszcz 2006.

Lazarii-Pawłowska I., Etyka. Pisma wybrane, Wrocław-Warszawa-Kraków 1992. 
McMahann J., Etyka zabijania, Warszawa 2012.

Owczarz W. (red.), Antologia praw zwierząt, Bielsko-Biała 1995.

Pietrzykowski T., Spór o prawa zwierząt. Etyczne problemy prawa, Katowice 2007.

Pietrzykowski T., Wyzwania moralne. Etyczne problemy prawa, Katowice 2010.

Probucka D., Filozoficzne podstawy idei praw zwierząt, Kraków 2013.

Singer P., O życiu i śmierci. Upadek etyki tradycyjnej, Warszawa 1997.

Singer P., Etyka praktyczna, Warszawa 2007.

Singer P. (red.), Wyzwolenie zwierząt, Warszawa 2011.

Singer P. (red.), W obronie zwierząt, Warszawa 2011.

Tokarczyk R.A., Biojurysprudencja. Podstawy prawa dla XXI w., Lublin 2008.

Waal de F., Małpy i filozofowie. Skąd pochodzi moralność?, Kraków 2013.

Ziobrowski J. (red.), Etyka u schyłku drugiego tysiąclecia, Warszawa 2013. 


\section{FROM OBJECT TO SUBJECT THE PRACTICAL CONSECVENCES OF ANIMAL ETHICS}

The paper touches upon fundamental questions connected with shaping the ethics of animal protection. It presents the historical process of evolution of attitudes towards animals, from reification to empowerment. For many centuries animals were treated as things, an object of rights to which humans were entitled, including the right of ownership. They were denied an ability of conscious feeling of pain, reason and self-consciousness. In view of the most recent scientific findings any further maintaining the paradigm of animal-thing (machine, automat) is unacceptable. An attitude of people towards other living species has significantly transformed over recent twelve years. This is testified by changes introduced to law (concerning, for example, reduction of cage breeding of chickens, ban on testing cosmetics on animals in the EU countries etc.). What confirms the aforementioned changes is also a rapid development of organisations working for the rights, interests and protection of animals. In ethics thee appear increasingly numerous discussions on the moral status, being a subject as well as human responsibilities towards other living creatures capable of feeling pain and suffering.

Keywords: reification of animals, animal ethics, animal liberation, the principle of equal consideration of interest 